\title{
Female Education in Nigeria: A Key to Development in ESAN North East Local Government Area, Edo State, Nigeria
}

Ebhomienlen, T. O.: Religious Management and Cultural Studies, Ambrose Alli University P. M. B. 14, Ekpoma, Edo State, Nigeria.

Aitufe V. O: Religious Management and Cultural Studies, Ambrose Alli University P. M. B. 14, Ekpoma, Edo State, Nigeria.

\begin{abstract}
This essay portrays Female Education in Nigeria as a key to Development in Esan North East Local Government Area, Edo State. The need to break the barrier of sex discrimination at the crucial time that Nigeria needs all round development is more appealing. The female folks are supposed to be co - pilots of the wheel of progress. It is evident in Esan North East Local Government Area that the traditional view of women has not drastically changed. Most women are still into petty business, like trading, farming, menial fashion making, hair making and so on. The new wind of change that is blowing in some parts of Nigeria has not sufficiently reflected in the area of this study. This study therefore, aims at encouraging females themselves and their parents to change their past view on education and respond positively on female education campaign initiates. To achieve the objectives of this essay the researcher adopts the historical, analytical and phenomenological methodology. It discovers that the training of girls/ women will enhance the social, political and economic status of women themselves and the society at large and this will form the bedrock for holistic development.
\end{abstract}

Key words: Female, Education, Equality, Development.

\section{Introduction}

Female education in Nigeria was almost a loss investment due to the nature of women as traditional beliefs held on them. Generally speaking the roles of women in Africa according to Fafunwa (1974) are mainly of child bearing, housekeeping and the sustenance of agricultural activities. Women are also seen as visitors or strangers in their maiden family. Investing on their education is seen as benefiting the martial family since in the first place, marriage changes their surname and secondly, more importantly marriage make them transfer all their identity to their husband's family - socially, economically and otherwise. This nomenclature has seriously affected the female folk in Esan, most especially in Esan North East local Government Area where the researcher under takes the study.

It is observed from the preferences for male education and anti - women education, which traces are still visible in most part of the world, is anti - development. The major channel through which both men and women could destroy the yoke of traditional and social oppression is education. Based on the disparity between men and women education the united Nation General Assembly in 1969 adapted a women (Awake Jan, 2008). Hence every November $25^{\text {th }}$ is declared as international day for the elimination of the violence against women.

The Esan women should be equipped to be partnership in Nation building. The level of women education is still far beyond expectation. This is evidence in the numbers of women engaged in petty trading, farming 
and other venial jobs in Esan North East Local Government Area, Edo State. This has contributed to slowing down the pace of development.

The Esan traditional axioms such as Ikpin ase ore amen and eki okhuo do meaning (when a python matures it goes into the river and a woman is a trader) serve as enough spectacle of viewing the traditional definition of women in relation to men. This has led to the gross under - development of women in Esan where this study is carried out.

Despite the global move against gender disparity it is obvious that Esan is far behind expectation as far as women education is concerned. For instance the United Nation World Conference on Woman in (1975) and the subsequent declaration of 1975 - 1985, as the decade for women was a feat towards women emancipation. The benefits of this decade were reinforced in 1995 and such other conferences. Although the result has not been so bad, however, it seems that this awareness has not gotten to grassroots. The feat to gear encouragement is the inspiration of the researcher. Since development trends require high powered skills, knowledge levels, competence, the acquisition of basic education as the case of most women in Esan is no longer adequate to enable them contribute effectively to national and communal development. The girl/ women must be encouraged to remain long enough in school to acquire requisites skills to partake in national building.

\section{Definition of Terms}

\subsection{Education}

Education is general terms is the process of transmitting societal norms, values, and describable attitudes from one generation to another. Education seeks to socialize individuals so as to equip them with the described mode of behaviour that is in conformity with the life of the people in the society in which they live. Education is the process of teaching and learning in schools and collages for the development of knowledge and skills so as to prepare individuals to live happily with themselves and others in the society where they live in however education means so many things to many people depending of their perception. To some means "knowledge", while others it means "enlightenment" or " wisdom".

Merriam Webster's Colleague Dictionary (1997) defines education "as the action or process of educating or of being educating or of being educated." It also sees it as the knowledge and development resulting from an educational process of shaping individual's behaviour for adequate adjustment in the society.

Fafunwa defines education as "the aggregate of all the processes through which a child develops abilities, attitudes and other forms of behaviour which are of the positive values to society".

Education covers a wide scope in human life. It is said that it starts from birth to death. Therefore education is the acquisition of knowledge, skills, values, and attitudes through imitation, observation, implementation, and teaching, learning in order to acquire the necessary behaviour for self and national development.

\subsection{Development}

To develop means "to make to become bigger, fuller and more elaborate" development is the process of being developed, a stage of growth or advancement (Illustrated Oxford Dictionary, 222); it is way of referring to something that has undergone or is undergoing a certain process making it significantly better than what it was in the past. In the context project development has to do with human persons and the environment.

\subsection{Education}

Education, in general terms, is the process of transmitting societal cores, values and desirable attitude from one generation to another. Education seeks to socialize individuals so as to equip them with the way of life of the society in which they live. Education is the process of teaching, training and learning in schools and colleges for the development of knowledge and skills so as to prepare individuals to live happily with themselves and others in the society where they live. However, various educators and educationists have offered series of definitions to education that must have pause to examine some of them here.

According to John Stuart Mill (1931) education includes whatever we do for ourselves and whatever is done for express purpose of bringing us nearer to the perfection of our nature. It comprehends even the indirect effects produced on character, and on the human faculties, by things of which the direct

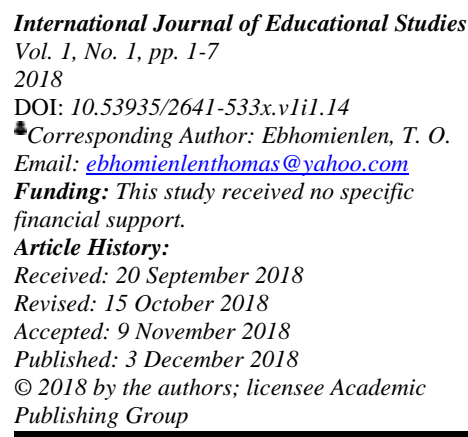


purposes are quite difference; by the industrial arts, by modes of life, nay, even by physical facts not dependent on human will; by climate, soil and local position.

This explanation further emphasizes the totality of education in its role as a refiner and regulator of human behaviour in the society. It does not only embrace the deliberate processes of schooling but includes even indirect and incidental influences. The core of education here is the culture which gives purposely to those who are to be it successors in order to qualify them for at least keeping up and if possible for raising the level of improvement which has been attainted.

To Chanhan (1976), education is the process of shaping individual's behaviours for adequate adjustment in the society. Fafunwa (1974) sees education as "the aggregate of all the processes through which a child develops abilities, attitudes and other forms of behaviour which are of positive value to society".

From these definitions the focuses of education is to imbue the individual with the knowledge, abilities, skills of behaviour to enable them function in their immediate environment and the society at large. However, the definition still fell short of telling us education is but its intent and processes.

Dr. Adiele (1975) defines education as "a desire change in human behaviour" while G Leonard (1967) says "to learn is to change. Education is a progress that changes the learners". These definitions are all one in their stand on a positive change in human as a mark of good education. Professor B. O. Ukeje (1973) says "the process of education occurs whenever any influence produces a change in the physical and mental behaviour".

An educated man is not necessarily a moral being or one that is aesthetically sensitive but the onus is on him to distinguish a moral question or an aesthetic question from a religious, political or scientific question. This will inform his reaction to issues at any point in time.

An educated man will be expected to show other characteristics like:

Realization of self;

Growth of the person;

Cultivation and development of one's own interest;

Development of a sense of individuality and historical perspective.

The educated should also behave in the value of truth, rationality and autonomy. Because of the value of truth and rationality we educated people rather than indoctrinate or merely trained them. It is only the educated that can act autonomously and pursue the goals of truth and rationality. In this perspective, an educated is knowledgeable, has breadth of understanding, can use knowledge in the most acceptable and appropriate manner and comport himself into an acceptable level, with the society's code of conduct.

\subsection{Development}

The term is derived from the verb "develop" which according to Oxford Advanced Learners Dictionary of Current English means to grow larger, fuller or more mature or organized. It can be conceived purely on physical, economic or quantitative terms based on noticeable growth. This means that the term development is very wide. Also, development means a general improvement in the life of the people, "the development of the people" (Adegboye, 1972), namely: their income, health, and their intellect or capacity to sustain the improved living conditions (Kocher, 1973). Development as pointed out by Arigbade (1990) consists of:

The daily efforts of the people to produce their life - supporting systems and themselves .... how they (i.e. The people) live harmoniously with nature, accepting and giving, not destroying ... the way a people's labour makes and advances their collective culture... the value that they place on the worth of the human being . . . how effective social justice is allowed to guide their social relations ... how much solidarity they manager to imbues their society with ... the extent to which every citizen comes citizen comes critically to feel that he or she contributes directly or defining the society's direction.

International Journal of Educational Studies Vol. 1, No. 1, pp. 1-7 2018

DOI: $10.53935 / 2641-533 x . v 1 i 1.14$

"Corresponding Author: Ebhomienlen, T. O. Email:ebhomienlenthomas@yahoo.com Funding: This study received no specific financial support. financial support.

Article History:
Received: 20 September 2018

Received: 20 September 2018
Revised: 15 October 2018

Accepted: 9 November 2018

Published: 3 December 2018

(1) 2018 by the authors; licensee Academic

Publishing Group

Development in general was often defined in economic terms as it was as a synonym of economic growth in terms of per capita income. For instance Yusufu (1996) wrote that development evolve when there are more inputs and more efficiency, which means an increase in output per unit of input. He went further to say that this changes the structure of outputs and in the allocation of inputs. The resultant growing economy in adversely generates development. These changes are as a result of combination of factors. First, in spite of some noticeable growth in per capita income, the developing nations are actually not developing as fast as they should. Meanwhile, the gap between them is the developed nations are growing instead of diminishing. Consequently, it has been observed by Kocher (1973) that despite some economic growth in most developing 
countries, social and economic welfare has improved very little because of unequal distribution of benefits. To buttress this point Hoffman (see Yusufu 1996) considered a country to be undeveloped when it is characterized by "poverty, with beggars in the cities, and villages eking out a bare subsistence in the rural areas. It is a country . . . usually with inadequate supplies of power and light. It usually has insufficient roads and railroads, insufficient government services, poor communication ... it may have isolated islands of wealth, with a few persons living in luxury ... another striking characteristics of under - developed country is that its exports to other countries usually consists almost entirely of raw materials, ore or fruits or some products with possibly a small or mixture of luxury handicrafts".

\subsection{Women in Development}

Women in development (WID), entered into the development lexicon after the Nairobi conference on women in 1985 and the subsequent production of a WID strategy in 1988, by the Department for International Development (DFID), which stressed the importance of integrating gender in all aid activities. This policy thrust has helped to put to put gender near the top of the development agenda for many international agencies and governments.

The need to include women as partners in development has necessitated the introduction of terms such as "gender sensitivity" in some public offices and assignments are allocated to women and the greater the number in such position the greater the gender sensitivity the leadership is deemed to express.

The initial understanding of such development is that it is still the men who decide what positions and assignment to be handed over to the women but a closer examination will show that such women as appointed to exalted position had excelled in their various fields of specialization and their achievement were what attracted them to their new bosses and sponsors. Both locally and internationally women are found in almost all area of endeavour like Medicine, Engineering, Law, Education, Pharmacy, Journalism, Police Force, (Ekiti State Police Commissioner) Entrepreneurship, and stock Exchange, Finance, Banking, Administration and Management, Politics.

The list is by no means exhaustive since there is hardly any area of development in which a woman or two cannot be found.

Most State Governors and the President of the Federation have been gracious in appointing women to positions of great responsibility ranging from Transition Committee chairman and members, Permanent secretaries, Commissioners, Directors to Ministers and Directors general of important and sensitive Parastatals. While this is commendable and really tends to change the trend, this development by no means addresses effectively the problem of marginalization of women in development programmes. The percentage of women who are in development is like a drop of water in the ocean with regard to the population of women who actually should be involved whether in the private sector or in the public sector. The need to get more women has focused our or an appeal to allocate a certain percentage of public offices to women. Thirty percentage $30 \%$ ) of the positions if allocated to women is regarded as acceptable, the question to be asked are:

- Why is such a cell necessary?

- Are women not computer literate or qualified enough to be into public service on their own?

- Have those women who have been in governance not performed creditably?

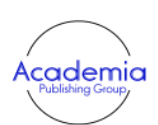

International Journal of Educational Studies Vol. 1, No. 1, pp. 1-7 2018

DOI: 10.53935/2641-533x.v1i1.14

Corresponding Author: Ebhomienlen, T. O. Email:ebhomienlenthomas@yahoo.com Funding: This study received no specific financial support. Article History:

Article History:
Received: 20 September 2018

Received: 20 September 2018
Revised: 15 October 2018

Accepted: 9 November 2018

Published. 3 December 2018

() 2018 by the authors; licensee Academic

Publishing Group

\subsection{Women and Development}

The Ministry of National Planning (1980), sees development as that of man in which he is able to improve his material conditions and living through the resources available to him, Weidner (1970), believe that, development is the process of growth in the process of growth in the direction of nation - building and socio economic progress. .. a process of acquiring sustained growth of systems capabilities to cope with new and continuous change towards the achievement of progressive political, economic and social objective.

Torado (1981), therefore, concludes that, development should be perceived as multidimensional that would involve institutional, social and attitude change. In view of these perceptions of development, to be able to make a significant impact, the women must understand the dynamics of the existing structures and appreciate the need for change and the direction and special technical skills that are necessary tools of action.

Generally, the across of women to education is very low and this attributed to the concept of women especially, in developing countries as chattels to be owned by men, socio - cultural beliefs and early pregnancy, imitations into adulthood of teenagers where they obtain and make preference which is common 


\section{Academia}

International Journal of Educational Studies Vol. 1, No. 1, pp. 1-7

2018

DOI: 10.53935/2641-533x.v1i1.14

Corresponding Author: Ebhomienlen, T. O.

Email:ebhomienlenthomas@yahoo.com Funding: This study received no specific

financial support.

Article History:

Article History:
Received: 20 September 2018

Received: 20 September 2018

Accepted: 9 November 2018

Published. 3 December 2018

(c) 2018 by the authors; licensee Academic

Publishing Group among most African countries, poverty which forces girls already in school out of school and into teenage marriage. These factors have helped to increase the population of illiterate women in society because these teenagers who drop out of school or not allowed to go to school at all eventually grow into women on whom dements towards development would be made. Furthermore, the policy document guiding women Education in Nigeria remain flimsy FRN, (2004), and the policy makers are predominantly men (Aderigbe, 2004), and so the women populace has remained largely illiterate. Babangida (1986) noted that, a nation cannot truly develop if her women remain illiterate, unskilled and unable to harness the resources in the environment and actually operating below their potentials. It is the ability to harness resources in their environment and improve on school environment that is the hallmark of development and most women cannot contribute effectively to development with the limited or basic education they acquire. Of course, high - powered education is available for the woman but how many of them have access to it. In poor families, priority will be given to the boys, at the expense of the girls social - cultural fixations discourages them from pursing discipline that will enable them benefit from the education they have acquired but simply queue up in the unemployment line. The resultant effect is what has been called "genderization of poverty" (Suara, 1996). The society also fails to get their contributions in the dimensions required for sustainable development. Research has shown that, the level of woman's education affect economic productivity, child health and welfare, family size and agricultural productivity in the rural areas which factors are indictors of development can hardly be satisfactory. It really seems as if women are deliberately excluded from participating in development.

\section{Equality and Women Empowerment}

Equality is a concept usually for granted especially in traditional communities when dealing with issues like age grade or other socio - cultural activities where equals are grouped together. In democracy, one of the cultural principles is equality before the law which interpreted means that if A receives a particular treatment before the law on a particular matter, B must receive the same treatment. Equality can also mean sameness, that is, one thing is the same as the other. Akinkpelu (1981) noted that, $3+3=6$, the sign of equity is the expression indicates that, the figure on the right is perfectly the same as those on the left of the equation when put together. It is very doubtful whether this is applicable on human affairs especially when dealing with gender issues in which roles and expectations are assigned.

In fact, such incidents of birth as sex, religion, culture etc already constitute social disparities, which we know, will influence access to education and other social benefit (Agu, 1994). In terms of education therefore, there will always be inequality between sexes. However, in order to attain a level of equality, there could be positive discrimination in favour of the group that is socio - cultural disadvantaged in other to be at par with its counterpart.

Women empowerment can be seen as the capacity of women to increase their self - reliant strategies through the inducement of education. The empowerment of women has been recognized as a pre - requisite for achieving effective and people - centred development and empowerment strategy.

In order to achieve equality through empowerment, there is need to:

- Increase the access of women to education, not just basic education but in the level will enable them appropriate the resources in their environment and still contribute effectively to its development.

- Improve on the quality of their achievement in relevant disciplines;

- Encourage the women/ girls to stay longer in school in order to acquire the necessary skills (retention/ persistence); and

Simply put, empowering women through education implies that the women will be fully supported to join male counterparts in acquiring formal education and the appropriate skills that will enable them complete favourable in the Job market or in the life market.

The United Nations Education and Cultural Association (UNECA) and United Nations Development Fund for Women (UNIFE, 2001) agreed that, education is necessary for the growth and development of every civilization. Nwaubani (2000) noted that, tertiary and University education is the bedrock of women empowerment and the best strategy to develop the potentials of women is to expose them to quality education at the highest level. 


\section{Economic Life of ESAN People}

Esan is an agricultural community with majority of the people being farmers. Their crops are yam, cassava, melon and banana, corn, cocoyam and groundnuts. Beans and vegetables are usually planted in their husband's farm. Most of the farm work is done by the men with the women rendering occasional helping hand.

The main economics crops were cotton. This was mainly planted by women. Cloth weaving became their major occupation of the female folks. Older women and mother who could weave train the younger ones. Recently rubber and pawpaw have become economics crops of the Esan people. Thus the Esan people practice mixed farming.

Most especially the Uromi people in Esan are known in the art of trading. They are like Onitsha in Ibo land. They are often referred to as the Ibo of Esan. Young men and woman are involved in trading, some sell creams, cloths, matches chewing sticks in the past (Ojeifoh, 2000).

Ojeifoh (2000) further reveals that there are great traders in fashion dress suits, imported shoes children wears etc. The Eki olele market day was a good testimony of the social advancement and the contributions of Uromi traders to the development in Uromi and Esan land (Ojeifoh).

\section{Female Education in Traditional Community in ESAN Land}

Before the advent of modernity the axiom of Esan people is eki okuo do (woman traders) and ikpin ase ore amen (when python matures it goes into the rivers). The hope of the female child was petty trading and helping the husband in the farm. As a child the mother would give her education in the area of sowing farm crops like beans, cotton, groundnut, melon and vegetables etc.

Besides, the farming experience, the Esan people are vast in cloth weaving and pot making. The popular regalia called igbuododo is woven in Uromi in Edo state. Mat weaving is most especially the trade of Uzea and Ugboha people. Pots (ache bi uwawa) are mainly made by the Ibori and Atuagbo people. However cloth and mat weaving is the major economic mainstay of the woman. Female children are educated on how to make the above items. The Esan girls were encouraged to be hardworking. There are songs, sung by older women to discourage idleness and laziness among the younger's ones. These songs are sung most especially during traditional marriages. One of them is

Abhalu aile ------ No work no eating

Abhalu aile ------- No work no eating

Abhalu aile ------- No work no eating

Obhiaha abhalu aile Bride, no work no eating.

Another one goes thus:

Obo men ikhe sa jo olulu bhi ighogho

Obo men ikhe sa jo olulu bhi ighogho

That is "a woman that waits for her husband leaves her cotton in the smoke of fire". The means of preserving cotton those days is sun and smoke of fire. After drying the cotton for a while in the sun, it would be wrapped and kept in a container in a place where fire is made. Lazy women kept theirs for indefinite time while the hardworking ones wove theirs to cloth for sale.

The advent of modern education in Esan land did not receive the expected welcome. Isedua Edenangbon (oral communication) revealed that the idea of parents was that school was met for lazy people and slaves. She furthered said that the first set of people who received western education were the weak and the outcast.

Another source, Otiti Okoduwa said that parents did not allow their female children to attend schools as they saw it as wasting of time. She also revealed that she married at the age of 14 or 15 years. This study discovered that women were preserved for their husband as the mothers of girls who married as virgins were rewarded. They believed that exposing them to modern education might lead them to sexual immorality. Hence the only option for younger women was petty trade and farming.

\section{Conclusion}

This paper discussed female education in Esan land. It demonstrated that the ratio of female education to male is very wide. The disparity tradition put on female and male education still linger on despite the impact of modernity. The number of Esan women in education in Esan land has not been able to break national political and administrative band except those in Diaspora, like other women in some ethnic groups in

Vol. 1, No. 1, pp. 1-7

Corresponding Author: Ebhomienlen, T. O Email: ebhomienlenthomas@yahoo.com financial support.

Article History:

Revised: 15 October 2018

Accepted: 9 November 2018

Published: 3 December 2018

( 2018 by the authors; licensee Academic

Publishing Group 
Nigeria. The study also observed that women themselves have not left the traditional platform inspite of free education programme sponsored by the UPN Government led by Governor Ambrose Alli in Edo State in 1980.

Another beautiful opportunity Esan women should key into is the provision of National teacher's institute. The teacher's institute offers TC 2, NCE, B.A/ BSC Ed and Postgraduate Diploma. Another advantage is the National Open University programme established by Olusegun Obasanjo led federal Government.

Education being the pivot where development rotates is necessary for holistic advancement. The woman in Esan land ought to respond positively to the campaign for education for all and knowledge for advancement in order to join the male counterpart drive the force of development forward in Esan land in particular and Nigeria in general.

\section{References}

Acholanu, C. O. (1995). Mother, the Afrocentric Alternative of Feminism, Owerri: Afa publishers.

Akahomen, D. O. (2010). Women education road map to building national. Journal of academics, 3(3).

Ajayi, T (2000). Gender Inequality: Implication for Progressive Contribution of Women towards National Development Studies, 2(2).

Akinkpelu J. A. (1981). An Introduction to Philosophy of Education. London: Mac Press.

Edenagbon, I. (2016) Oral Communication.

Fafunwa, A. B. (1974). History of Education in Nigeria. London: George Allen and Uniben.

Hornby, A. S. (2005). Oxford Advanced Learner's Dictionary. London: O.U.P.

Klvasi Wired (1980). Philosophy and an African culture. London: Cambridge University Press.

Merriam Websters Collegiate Dictionary (1997). USA: Merriam Webister, incorporated.

National Teachers Institute (2010). General method in education (PGE 103) Kaduna: NTI.

Nwaubani Q. O. (2000). Women education and National development in Nigeria in Issues in Nigeria education. Lagos: Makugamu Press.

Ojeifoh, A. P. (2000). Uromi Chlonicles 1025 - 2002, History Culture and Customary Law. Uromi: Aregbeyeguale Publishers.

Okoduwa I. (2016). Oral Communication.

Oseghale F. and Oriahi C. I. (2006). Perspectives in Women Education in the $21^{\text {st }}$ Century. Journal of Academics, 1(1). United Nations Development Fund for Women (2001). Women empowerment administrations in Asia. Durhan: Duke University Press. 